\title{
ピッチが付着し難い中芯紙及びジュートライナーマシーン用の ライダーロールの開発*
}

株式会社野村鍍金 技術部 ○仲井 啓治，中山 恵次

\section{Development of New Coating Material for Rider Roll in Winder, Having Characteristic of Resisting Trouble with Pitch Sticking to Roll Surface, Concerning Latest Corrugating and Jute Liner Board Machine}

Keiji Nakai and Keiji Nakayama

Technical Development Division, Nomura Plating Co., Ltd.

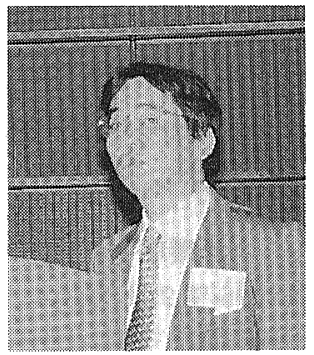

仲井啓治

In case of operation for Corrugating paper and Jute Liner board machine, corrugated waste paper and magazine waste paper are using, as main raw materials. In latest tendency, the content of waste paper are gradually increasing, and in almost Corrugating paper machine, they are keeping perfectly $100 \%$ waste paper. In component of waste paper, each kind of Hot Melt, Wax, Gum type materials and Film etc. are generally mixing.

Owing to thease environment, winder operation for above system machine, are having some trouble with pitch sticking to surface of present Rider roll (made by steelpipe), and in some factory, they are much suffering from noise pollution, cause by pitch sticking.

In consideration of above mentioned condition, and customer's request for resisting trouble with pitch sticking, our company have decided to make project for settlement of trouble. By means of repeating several test, for resisting pitch sticking, we have succeeded with developments of new materials for outside cover of Rider roll.

Keywords: waste paper, corrugating machine, rider roll in winder, pitch sticking trouble, noise pollution by pitch sticking, developments of new materials

\section{1.はじめに}

A 級中芯紙の主原料は，一般に広葉樹の SCP また はCGP が用いられる。一方， B 級及び C 級の中芯紙

*平成 9 年度年次大会講演（講演 No.B 2-30）
の場合には段古紙，雑誌古紙が主原料となっている。 そして古紙には，ホットメルト，ワックス，ガム状物 質, フィルム等の異物（これらの買物を総称して“ピ ッチ”と言われることが多い。）が混入して扔りこ れが操業上のトラブルの原因ともなっている。これは, 古紙を主原料とする B 級や C 級のジュートライナー 
にも共通することである。

従来，パルプ芯は長網抄紙機で，また特芯は円網抄 紙機で抄造されていたが，現在では中芯の種別に無関 倸に長網抄紙機が多く採用されており，さらに最近で は, 高速化と品質への対応で, ッインワイヤーのマシ ーンも稼㗢している。

一方，抄紙機のワインダーに装着されているライダ 一ロールは, 従来から鋼管製のものが主体で, まれに クロムめっき被覆してあるものもあるようである。中 芯紙及びジュートライナー用のワインダーでのライダ 一ロールの装着場所とその概略構造を図 1 に示す。そ して, 古くから原料中のピッチがライダーロールの表 面に固着する操業上のトラブルが若干あったようであ るが, 近年に至って古紙含有率の增加と古紙の成分変 動と言うこともあって, ライダーロールへのピッチト ラブルが顕著に增加している。

\section{2. 特定のワインダーに於けるライダーロールの}

\section{使用実態と要望}

\section{1 ユーザーの使用実態と要望}

1995 年 10 月〜 1996 年 9 月の 1 か年を費やして, 実 際に B，C級紙の中芯紙, ジュートライナ一抄造メー カーに出向き, ワインダーのライダーロールに見られ る問題点を調査したところ, 14 工場/25台のワインダ 一に於いて，いずれもピッチの固着が激しく，その対 策としてクロムめっきを被覆したり, テフロンシート 巻を試みたり，あるいは夕ングステンカーバイトを溶 射したり，一応は，何らかの対策を実施した経緯があ るようであったが, 異口同音にその効果は, 1 2 か 月間で消失すると言うものであった。つまり，ピッチ 固着防止対策に効果はあっても短寿命過ぎて半ばあき

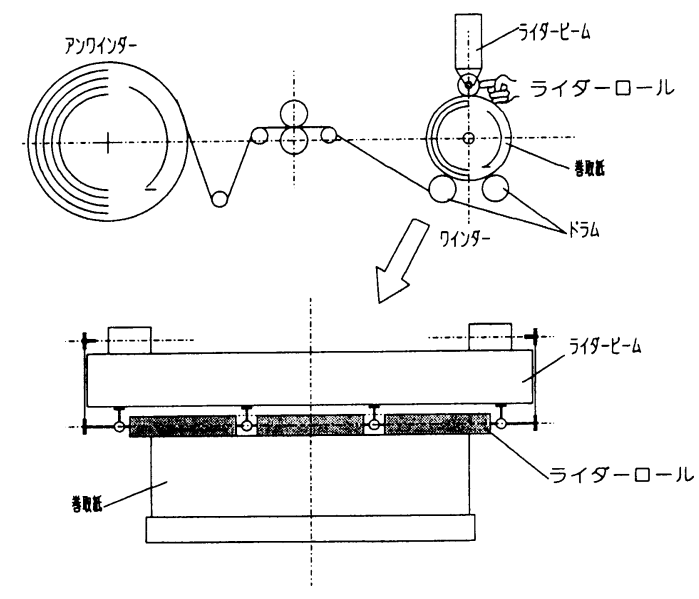

図 1 中芯紙のワインダーとライダーロール
らめの状態となっているようで，この意味では，ピッ 千固着対策に有効な表面被覆材料は，未だ発見ないし 開発出来ていないと言って良い。従って，ユーザーの 要望としては, ピッチの固着しないライダーロールを 開発して欲しいと言う意見が多い。

\section{2 特定ユーザーでの使用実例}

$\mathrm{A}$ 製紙会社の某工場の中芯紙の場合は，全て古紙 で抄造されており，ワインダーのライダーロール（鋼 管製）の表面にピッチが固着し，操業時に 90 100 $\mathrm{dB}$ にも及ぶテンダーにとって耐え難い程の騒音が発 生すると言うものであった。ここに於いて, 騒音の発 生原因は, 充分解明されていないがピッチの固着と機 械構造的なものが関与する複合的なものと推測され， 少なくともライダーロールの表面からピッチを除去す るだけで確実に音量が 10 20 dB 程度低下すると言 う事実がある。

それでは, この工場のワインダーのライダーロール に固着するピッチは，どのようなものから構成されて いるのかを化学的に調査すると, 一部にシリカ系の成 分を含んでいるもののガムテープの成分であるエチレ ン酢酸ビニル共重合体が主体であることが分かった。 また，この工場では，ピッチ固着防止対策として現在 迄に, $200 \mu \mathrm{m}$ 厚のテフロン（静電粉体塗装による $\mathrm{PFA}$ 樹脂) コーティング，500 $\mu \mathrm{m}$ 厚のアフロン（同 ETFE 樹脂）コーティングそれに $10 \mathrm{~mm}$ 以上の肉厚 のポリプロピレン被覆（ポリプロピレン管挿入）を卜 ライアルしており, これらの寿命は, テフロンで約 1 か月, アフロンで約 2 か月, ポリプロピレンでは約 4 か月と言うものであった。すなわち，これらの被覆材 はいずれも短期間ながらピッチ固着防止効果があった が，余りにも短寿命過ぎて本格採用に至っていないと 言うのが真相である。

\section{3 使用済ライダーロールの調查事例}

$\mathrm{A}$ 製紙会社の某工場で実際に 4 か月間使用した結 果, a.ピッチの固着が激しくなり，b. その結果, 騒 音低減効果が消失し, c. 同時に紙にシワが発生して 取り外された上述の厚肉ポリプロピレン被覆ライダー ロールを当社が調査した結果を簡単に取りまとめると 以下のようである。

(1) 3 本のロールそれぞれにゴム状の黒色異物が固 着しており，場所によって固着の程度に差異が見 られた。またロールの円周方向に濃淡を持って筋 状に固着しており, 固着状態にはいずれのロール にも規則性がない。

（2）付着物をトルエンで擦って溶解除去し，表面を 観察するとそれぞれのロールの両端部分にクラッ 
クが入り，また摩耗も相当進行して表面がイレギ ュラー面となっていた。

以上の結果から次に述べる考察が成り立つ。

(1)ライダーロールの表面被覆に適する材料は, 耐摩 耗性があって，ピッチ等がロール表面に固着せず に非粘着性が維持出来る被覆材料でなければなら ない。

(2)一旦ピッチが固着すればロール表面に粘着性が現 れ，紙離れ時に騷音が発生し，またピッチの固着 が不均一であるがゆえにロール表面が凹凸を呈し， その結果，巻取られる紙に“シワ”が発生する。

\section{4 ライダーロールでの騒音発生要因の分析と騒} 音発生モデル

（1）ライダーロールでの騒音発生要因の分析

ライダーロールの騷音発生要因を明らかとする為に は, ライダーロール支持軸受部の振動計測が必要とな るが, 現時点で騒音発生要因を推定すれば,

(1)ロール表面の摩擦係数の変動…局部的なピッチの 付着

(2)ロール表面の凹凸化……………ロール表面の凹み

(3)ロール表面の多角形化…………ーールの回転変動 化

(4)巻取紙外面の振れ

などである。すなわち騒音発生は，上記(1)（4)のいず れかの現象によってライダーロール（支持部を含む） の共振現象を誘発している可能性が高い。

一方，騒音側に立った対策であれば，

a. ライダービームの剛性アップ（固有振動数の 增大)

b. ライダーロールの押し付け荷重の増大

などで，ある程度低騒音化が可能と推定される。

なお，厚肉 $(14 \mathrm{~mm})$ のポリプロピレン被覆したラ イダーロールで $10 \mathrm{~dB}$ 程度騒音の低減が四れたこと は，金属の場合と比べてライダーロール表面の剛性が 著しく低い為に振動の減衰効果が大きいせいであると 考えられる。

(2) ライダーロールでの騒音モデルの推定

ワインダーのライダーロールの運転モード例とピッ 千固着がある場合とない場合の推定される騒音モデル を図 2 に示す。

3. ワインダーのライダーロールに対する当社の 基本方針

当社は, 従来から製紙業界で要望される防錆処置・ 耐摩耗性付与 - 污染対策 - 耐熱性付与 - 潤滑性付与 光沢付与等の諸問題を全て取り上げて対応すると言う

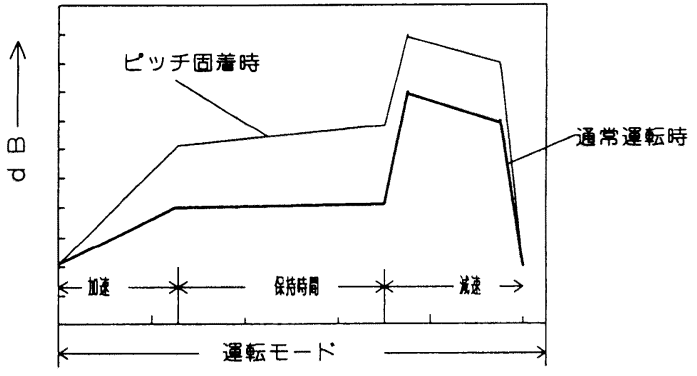

図 2 運転のモードと騒音発生の推定モデル

方針を打出しており，この意味では，現在ピッ千固着 で困っているワインダーのライダーロールも例外では なく，長期間に亘ってピッチの固着がなく，騒音低減 に効果を示すライダーロールの表面被覆材の開発に着 手した。

\section{4. ライダーロールに適する表面被覆材の選定の} 為のフォアキャスター試験

\section{1 ライダーロール用被覆材料の選定}

事前に 20 種類にも及ぶ表面被覆材料をリストアッ プし，50 mm 角のSS 400 の表面に実際に被覆した後， 表面粗さを $2 \mu \mathrm{Ry}$ 以下に揃えて，これらの表面にエ チレン酢酸ビニル共重合体を主成分とする接着片を一 定量塗布乾燥させて碁盤目試験で付着性の優劣を付け, 最終的に表 1 に示方表面被覆材料をフォアキャス夕ー 試験用として選定した。なお，クロムめっきについて は，参考迄に中芯紙との接触面積が少なくなる梨地ク ロムめつきを加えた。

\section{2 フォアキャスター試験用テストリングの形状} テストリングの形状を図 3 に示す。

\section{3 フォアキャスター試験でのピッチ付着テスト} 要領

4.2 項のテストリングに 4.1 項の表 1 で示した選定 被覆材料を施したものを準備し, 図 4 の要領でピッチ 付着テストを行った。また, 予備テストの結果, テス 卜条件を以下の範囲で設定した。

・テストリングニップ圧 $\cdots 26 \sim 90 \mathrm{~kg} / \mathrm{cm}$

・運転スピード………....50 200 m/分

・運転時間 合計 3 週間

\section{4 ピッチ付着テストの結果}

以上のピッチ付着テストは，一度実機のワインダー で巻き取られているせいか 3 週間の運転にも関わらず, いずれのテストリングにも思ったようにはピッチ付着 が生じなかった為にやむなくリングの污れの程度をピ ッチ付着に置き換えて判定した。結果を表 2 に示す。 
表 1 ライダーロール用として選定した被覆材料

\begin{tabular}{c|l|c|c|l}
\hline No. & \multicolumn{1}{|c|}{ 被覆材料 } & 被覆厚 & 仕上粗さ & \multicolumn{1}{|c}{ 特 記 事 項 } \\
\hline 1 & 鉄芯 $(\mathrm{SS} 400)$ & - & $0.8 \mu \mathrm{Ry}$ & 比較用材料 \\
\hline 2 & クロムめっき & $50 \mu \mathrm{m}$ & $0.8 \mu \mathrm{Ry}$ & 通常のバフ仕上げ \\
\hline 3 & 梨地クロムめっき & $50 \mu \mathrm{m}$ & $50 \mu \mathrm{Ry}$ & 通常のクロムとの比較 \\
\hline 4 & 溶射 $\mathrm{A}$ & $100 \mu \mathrm{m}$ & $0.4 \mu \mathrm{Ra}$ & \\
\hline 5 & 溶射 $\mathrm{B}$ & $100 \mu \mathrm{m}$ & $0.4 \mu \mathrm{Ra}$ & \\
\hline 6 & 溶射 $\mathrm{C}$ & $100 \mu \mathrm{m}$ & $0.4 \mu \mathrm{Ra}$ & \\
\hline 7 & 特殊テフロン & $100 \mu \mathrm{m}$ & $0.8 \mu \mathrm{Ry}$ & \\
\hline
\end{tabular}

表 2 各種被覆材とピッチの付着

\begin{tabular}{l|l}
\hline \multicolumn{1}{c|}{ 被 覆 材 料 } & \multicolumn{1}{c}{ ピッ付着程度 } \\
\hline 鉄芯 $(\mathrm{SS} 400)$ & $\bigcirc$ \\
\hline 通常のバフ研摩クロム & $\bigcirc$ \\
\hline 梨地クロム $(50 \mu)$ & $\bigcirc 0$ \\
\hline 溶射 $\mathrm{A}$ & $\bigcirc 0000$ \\
\hline 溶射 $\mathrm{B}$ & $\bigcirc \bigcirc$ \\
\hline 溶射 $\mathrm{C}$ & $\bigcirc \bigcirc$ \\
\hline 特殊テフロン & $\bigcirc 0000$ \\
\hline
\end{tabular}

○の数の多い程ピッチ付着が少ないことを意味する。

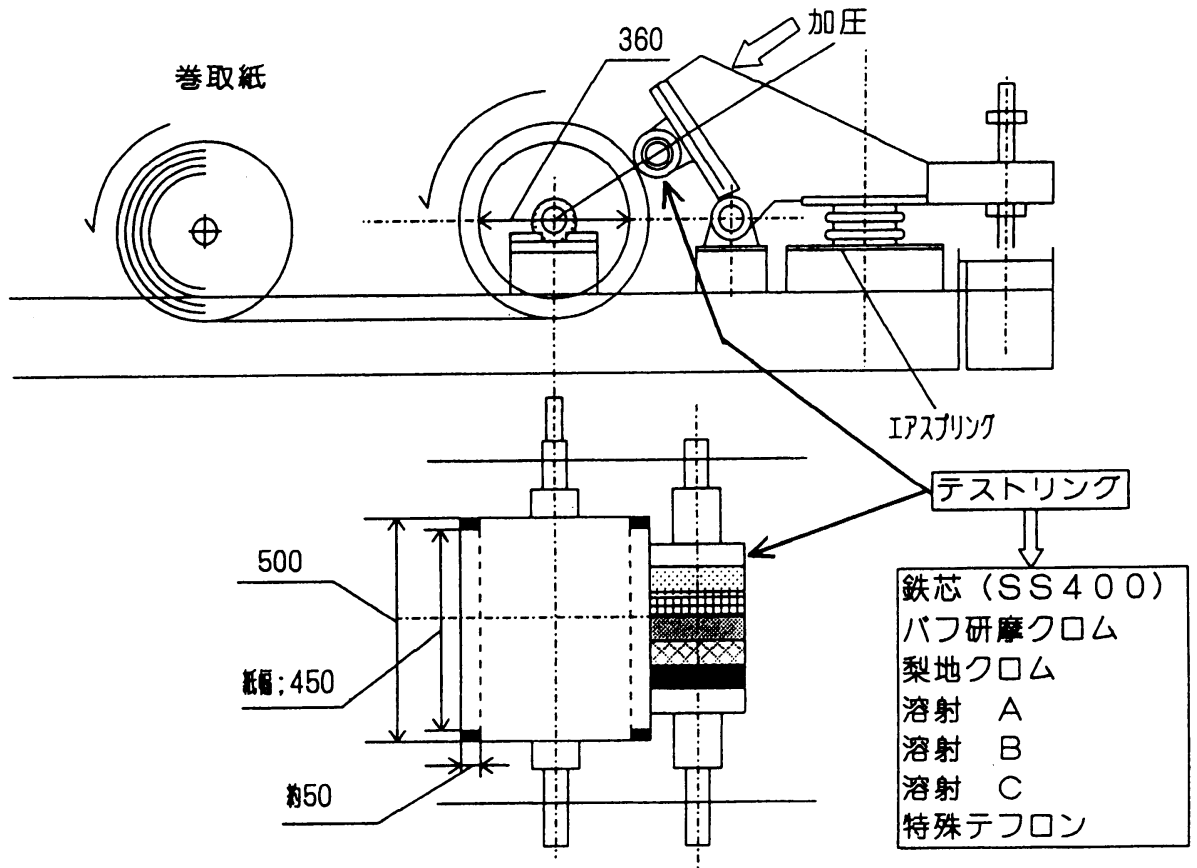

図 4 ピッチ付着テスト要領 
この結果によると溶射 $\mathbf{A}$ と特殊テフロンがピッチ 付着が少ない被覆材料であることを確認出来たが，テ スト条件を低速で高ニップ運転としていることや一度 ワインダーに掛けられてバージンピッチが取り除かれ ていることなどを勘案すると実機の標準的な運転速度 である $2,000 \mathrm{~m} /$ 分でピッチ付着にどれ程効果を発揮 し，また寿命的にも充分なライフがあるのかは全くの 末知数である。従って, 溶射 $\mathrm{A}$ と特殊テフロンにつ いて耐久性（寿命）の比較テストを実施することつし た。

\section{5 特殊テフロンと溶射 $\mathbf{A}$ の寿命比較試験}

（1）たわみ加圧ロール方式による加速試験

基本的には, 図 4 に示してある $360 \mathrm{~mm} \phi \times 500 \mathrm{~mm}$ 長さのロールをフリーの状態とし，これにキャンバス を掛けて面長方向 4 筒所でモノマロンを使ってキャン バスの外側から加圧した。この試験の要領を図 5 に示 す。
（2）壁加圧ロール方式による加速試験

上記(1)では，摩耗加速試験としてたわみ加圧ロール 方式を述べたが，ワインダーのライダーロールの運転 状態を勘案して, 別個に壁加圧されることを想定した 加速試験を実施することにしたが，この試験要領は， (1)の図 4 の $360 \mathrm{~mm} \phi$ のロールの左に入手した中芯紙 を片側 $50 \mathrm{~mm}$ 巻いて直径を $600 \mathrm{~mm}$ とした 500 $\mathrm{mm} \phi \times 500 \mathrm{~mm}$ 長さのロールを配置し, ネジ方式で それぞれのロールをタッチさせて実施したもので, 図 6 にその試験要領を示す。

(3) 加速試験の条件

2 種類の加速試験の要領は, それぞれ 1)，2）で記述 したが, 加速試験の為の運転条件は, 実機の運転条件 に出来るだけ近付ける為に, 図7のようなタイムス夕 ディで 75 回 (計 300 分) 運転した。但し, 壁加圧口 一ル方式の場合には, 1 回運転ごとに巻取紙を剝がし て新なな表面を出した後，次の運転に入った。

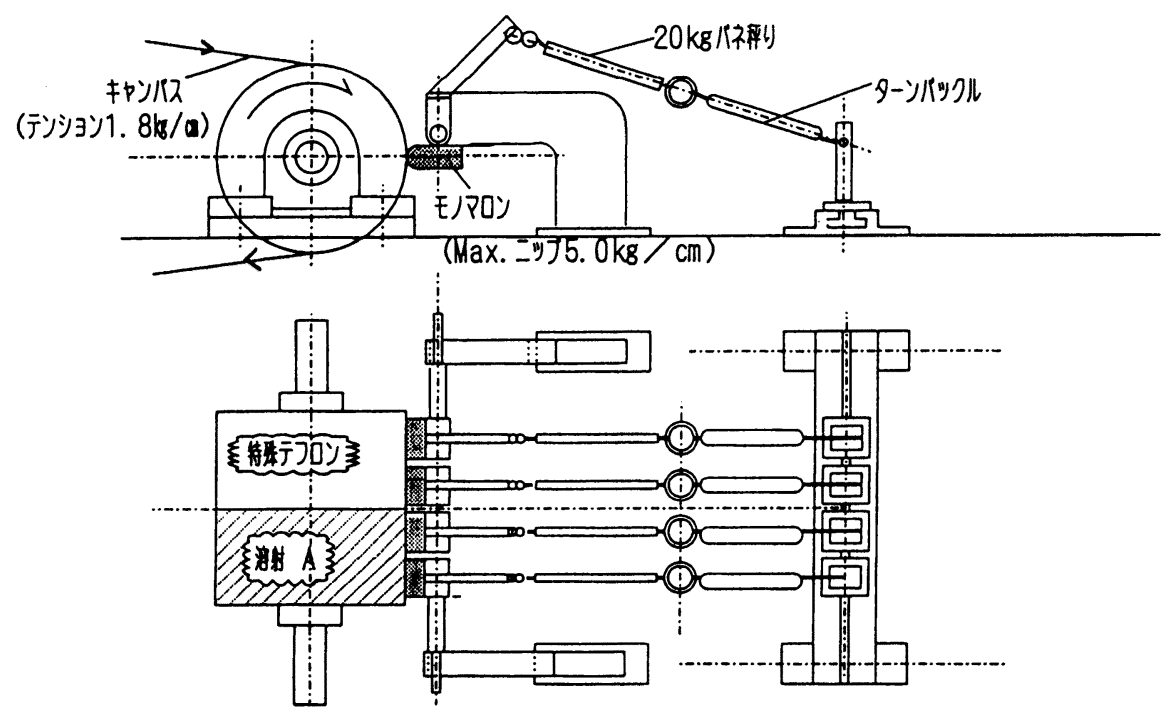

図 5 たわみ加圧ロール方式の試験要領

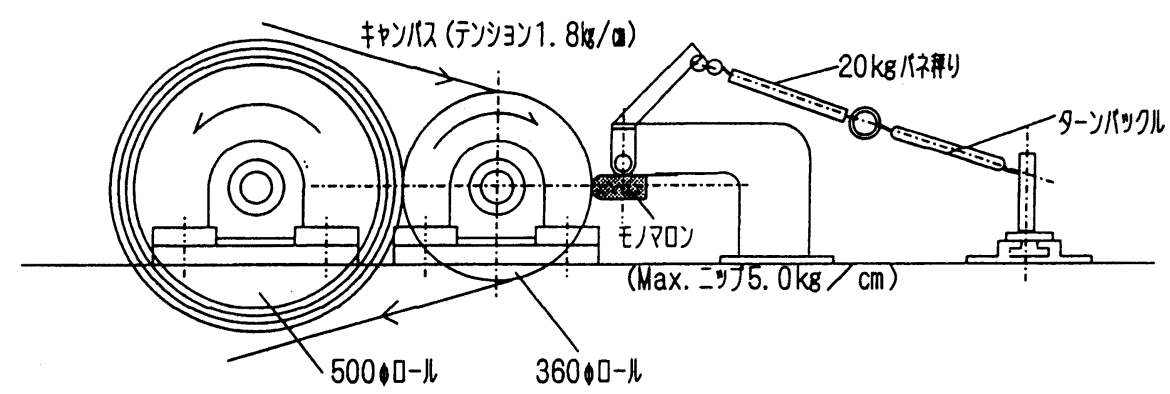

図 6 壁加圧ロール方式の試験要領 


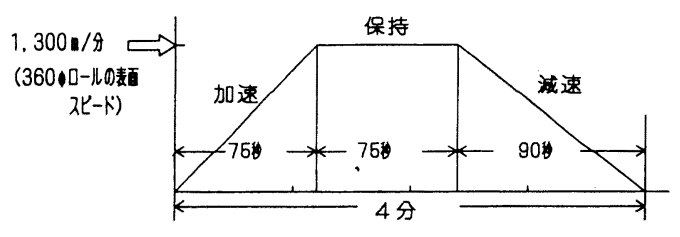

図 7 加速試験のタイムスタディ

(4) 加速試験の結果

表 3 の通りで, 壁加圧ロール方式に於いて初めて溶 射 $\mathrm{A}$ と特殊テフロンに差異が見られたので, 実機に 対しては, 溶射 $\mathbf{A}$ を適用することに決定した。

\section{5. 溶射 $\mathbf{A}$ の割れに関する机上検討}

以上の一連のフォアキャスター試験で溶射 A がワ インダーのライダーロールの被覆材料として好ましい ことが分かったが, 一般にめっき被膜やテフロンと比 べると溶射材料は, 硬度が高く, 尚且つ脆いと言うの が定説で実機運転中に割れて飛散すると言う事故を起 こす危険性も想定されたので, 実際にワインダーのラ イダーロールに被覆したと言う前提で割れ発生有無に ついて机上検討することとした。なお，ライダーロー ルは, 実機でのトライアルを予定している A 社の B 工場のものを対象として検討した。

(1) 接触面圧についての検討 a. ライダーロール径 : $262 \mathrm{~mm} \phi\left(\mathrm{r}_{1}=131 \mathrm{~mm}\right)$

b. 溶射被膜のヤング率 : $\mathrm{E}_{1}=15,000$

c. 溶射被膜のポアソン比: $\nu_{1}=0.26$

d. 巻取紙最小径（紙管径）: $120 \mathrm{~mm} \phi\left(\mathrm{r}_{2}=60\right.$ $\mathrm{mm})$

e. 紙管のヤング率 : $\mathrm{E}_{2}=500$ (推定値)

f. 紙管のポアソン比： $\nu_{2}=0.3$

g. 線圧 : $\mathrm{N}=\max .3 \mathrm{~kg} / \mathrm{cm}(0.3 \mathrm{~kg} / \mathrm{mm})$

また溶射被膜の運動疲労度は, $\mathrm{P}_{\mathrm{HW}}=37 \mathrm{~kg} / \mathrm{mm}^{2}$ であり, 実機に於ける線圧の変動が 2 倍あるとしても 被膜の割れに対する安全率は,

$$
\mathrm{f}_{1}=\frac{37}{1.57}=23.6 \text { となる }
$$

(2) ライダーロールの曲げ応力についての検討 ロール表面の溶射被膜には, 両振りの繰り返曲げ応 力が作用することになり，このケースでの溶射被膜の 安全率は, 仮に溶射被膜に繰返し外力が作用した場合 の割れ発生疲労強度を $12.03 \mathrm{~kg} / \mathrm{mm}^{2}$ とし, 実際の 2 倍の曲げ応力が作用したとしても安全率 $\mathrm{f}_{2}$ は,

$$
\mathrm{f}_{2}=\frac{12.03}{0.175 \times 2}=34.4
$$

すなわち, 溶射被膜に掛かる接触面圧, 曲げ応力な どの作用応力を負荷線圧側の 2 倍で算定しても溶射被 膜の割れ発生に対する安全率は, いずれも高く, 実運

表 3 たわみ加圧ロール方式と壁加圧ロール方式による摩耗比較試験結果

\begin{tabular}{c|l}
\hline \multicolumn{1}{c|}{ 加速試験 } & \multicolumn{1}{|c}{ ロール被覆材料の摩耗状態 } \\
\hline たわみ加圧ロール方式 & ロールの摩耗状態には, 溶射 $\mathrm{A}$, 特殊テフロンとも全く変化なし。 \\
\hline 壁加圧ロール万式 & $\begin{array}{l}\text { ロールの摩耗状態は, 溶射 } \mathrm{A} \text { が全く異常がないのに対して特殊テ } \\
\text { フロン側に若干の摩耗兆候あり。 }\end{array}$ \\
\hline
\end{tabular}

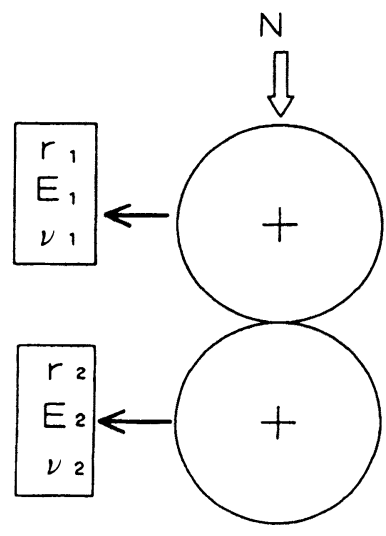

$Q^{2}=\frac{1}{\pi}\left(\frac{r_{1}+r_{2}}{r_{1} \times r_{2}}\right)\left(\frac{N}{\frac{1-\nu_{1}^{2}}{E_{1}}+\frac{1-\nu_{2}^{2}}{E_{2}}}\right)$

$Q$ : 最大接触ヘルツ面圧

$=0.00773 \times 531.3 \times \mathrm{N}$

$=4$. $1069 \mathrm{~N}$

ここて

$\mathrm{N}=0 . \quad 3 \mathrm{~kg} / \mathrm{mm}$ のとき $Q^{2}=1.232$

$Q=1.11 \mathrm{~kg} / \mathrm{mm}^{2}$

$N=0.6 \mathrm{~kg} / \mathrm{mm}$ のとき $Q^{2}=2.464$

$Q=1.57 \mathrm{~kg} / \mathrm{mm}^{2}$

図 8 


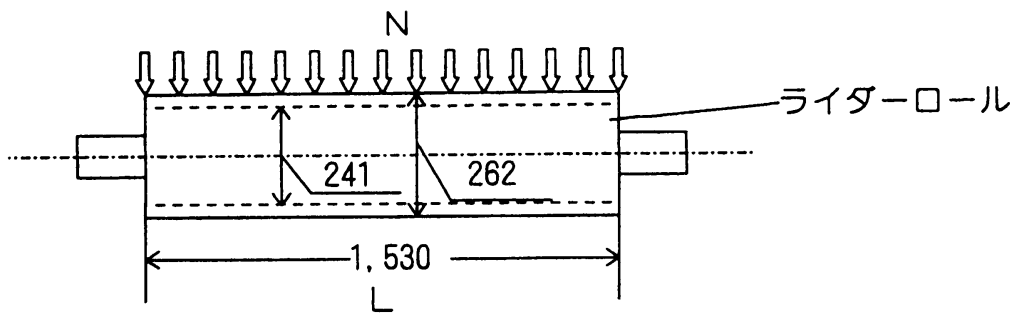

$$
\begin{aligned}
\mathrm{Mmax} & =\frac{1}{8} \mathrm{NL}^{2} \quad(\mathrm{~N}=0.3 \mathrm{~kg} / \mathrm{mm} \text { とすれば }) \\
& =8.77 \times 10^{4} \mathrm{~kg} \cdot \mathrm{mm} \\
Z & =5.015 \times 10^{5}\left(\frac{\pi}{32} \times \frac{262^{4}-241^{2}}{262}\right) \\
\sigma_{\mathrm{b}} & =\frac{M m a x .}{Z}=0.175 \mathrm{~kg} / \mathrm{mm}^{2}
\end{aligned}
$$

図 9

転で割れ発生の危険性は極めて少ないと結論出来る。

\section{6. おわりに（実機への適用）}

最近の中芯紙及びジュートライナーマシンのワイン ダー用ライダーロールは, 使用原料事情の変化やマシ ーンの高速化でピッチの付着トラブルの増加とその結 果としての騒音の発生と言う操業上の問題を抱えてお り，この解決に有効である被覆材料として“溶射 A” を開発した。“溶射 A”は, 現在 A 社の B工場に実 機トライアルとして納入運転中で, 使用開始後 3 力月 目を経過し，4 月月目に入っている。

ちなみに B 工場のライダーロールは, $262 \mathrm{~mm}$ 径 $\times$ $1,530 \mathrm{~mm}$ 長さを 1 本として 3 本 1 組で使用されるも のである。また，使用中のテンダーの報告では，

(1)溶射 A を被覆することによって騒音量が確実に
低下した。

(2)ピッチの付着は，皆無ではないが鋼管製ロールに 比べると同一運転期間での付着量とその堆積厚み が圧倒的に少なく，またピッチも固着と言うより も付着に変化して除去しやすくなった。

(3)ピッチが付着すると若干運転時の音量が増加する が，それでも鋼管製のロールに比べると静かであ る。

と言う中間結果となっている。当社としては, 定期的 にピッチを除去する必要性はあるものの, テンダーに とって除去しやすい状態にまで改善されており, 後は ロールの寿命を見極めると共に，さらにピッチ付着を 低減出来るライダーロール被覆材開発に努める所存で ある。 